\title{
TEST ANXIETY IN PRE-EXAM PERIOD AND SUCCESS OF NURSING STUDENTS
}

Goran Stojanovic ${ }^{1}$, Milica Vasiljevic-Blagojevic ${ }^{1}$, Bratislav Stankovic ${ }^{1}$, Negra Terzic ${ }^{1}$, Dragana Terzic-Markovic ${ }^{1}$, Dusan Stojanovic ${ }^{2}$ ${ }^{1}$ High Medical College of professional Studies in Belgrade, Serbia

${ }^{2}$ Dea medica, Belgrade, Serbia

\author{
ISPITNA ANIKSIOZNOST U PREDISPITNOM PERIODU \\ I USPEH STUDENATA SESTRINSTVA

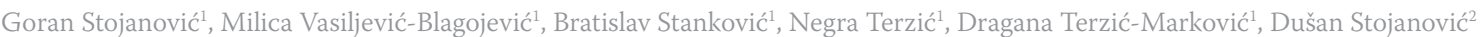 \\ ${ }^{1}$ Visoka zdravstvena škola strukovnih studija u Beogradu, Beograd, Srbija \\ ${ }^{2}$ Dea medica, Beograd, Srbija
}

Received / Primljen: 25. 10. 2016.

Accepted / Prihvaćen: 05. 01. 2017.

\begin{abstract}
The aim of this study was to examine the presence of preexam anxiety in nursing students and establish relationship of pre-exam anxiety intensity in relation to the category variables (gender, age, place of birth, current place of residence, with whom they live, whether they are employed, the average family income, year of study), objective success (i.e., pass rate at exams, the average score at the end of year, possible renewal of the year of study) and the subjective perception of academic success (i.e., self-satisfaction as a student as well as the importance of ratings obtained at the exam). The sample was random and consisted of the students of High Medical College of Professional Studies in Belgrade at the Department of vocational nurse. 209 students were tested, evenly distributed on the second and third year of study. Pre-examination anxiety among students was examined using a questionnaire The Test Anxiety Inventory - TAI (Test Anxiety Inventory), which includes subscales: Test Anxiety Inventory-Total (TAI-T), Test Anxiety Inventory-Worry (TAI-W) and Test Anxiety Inventory-Emotionality (TAI-E). From the obtained results we can conclude that nursing students showed a statistically significant pre-exam anxiety on all subscales. Preexam anxiety symptoms compared to candidates' sex showed statistically significant differences in all scores, and average values are always higher in female students compared to male. There is also a statistically significant difference between students of the second year in relation to the third year students. It can be concluded that there is a significant number of nursing students with the pre-exam anxiety problems that need professional help and support in the form of expanding and strengthening personal competencies.
\end{abstract}

Keywords: students, study nursing, pre-exam anxiety, stress, exams

\section{SAŽETAK}

Cilj istraživanja je bio da se ispita prisustvo predispitne anksioznosti kod studenata sestrinstva $i$ utvrdi povezanost intenziteta predispitne anksioznosti u odnosu na kategorijalne varijable (pol, uzrast, mesto rodenja, trenutno mesto stanovanja, sa kim žive, da li su zaposleni, prosečna primanja porodice, godinu studija), objektivni uspeh (prolaznost na ispitima, prosečna ocena na kraju godine, moguće obnavljanje godine studija), i subjektivnu percepciju akademskog uspeha (zadovoljstvo sobom kao studentom kao $i$ važnosti dobijene ocene na ispitu). Uzorak je slučajan i sačinjavali su ga studenti Visoke zdravstvene škole strukovnih studija u Beogradu na studijskom Odseku strukovna medicinska sestra. Testirano je 209 studenata, ravnomerno rasporedenih na drugu i treću godinu studija. Predispitna aksioznost medu studentima je ispitivana pomoću upitnika za merenje anksioznosti Instrument za ispitivanje aksioznosti eng. Test Anxiety Inventory (TAI), koji sadrži nekoliko subskala: Test Anxiety Inventory-Total (TAI-T), Test Anxiety Inventory-Worry (TAI-W) $i$ Test Anxiety Inventory-Emotionality (TAI-E). Iz dobijenih rezultata možemo zaključiti da studenti sestrinstva pokazuju statistički značajnu predispitnu anksioznost na svim subskalama. Simptomi predispitne anksioznosti u odnosu na pol kandidata pokazali su statistički visoko značajne rezlike kod svih skorova, odnosno prosečne vrednosti su uvek veće kod studenata ženskog pola u odnosu na muškarce. Istraživanje je pokazalo da je postojao značajan broj studenata sa prisustvom predispitne anksioznosti $i$ koji su zahtevali profesionalnu pomoć i podršku u formiranju, jačanju i proširenju ličnih kompetencija.

Ključne reči: studenti, anksioznost, stres, ispiti

\section{ABBREVIATIONS}

TAI - Test Anxiety Inventory TAI-T - Test Anxiety Inventory-Total
TAI-E - Test Anxiety Inventory-Emotionality TAI-W - Test Anxiety Inventory-Worry

Sd - Standard deviation 


\section{INTRODUCTION}

Anxiety is a form of pathological fear characterized by a feeling of inner restlessness, timidity and concern. It occurs when there is no real danger or when the emotional response is not commensurate with the experience of risk (1). Fear of exams and tests has the greatest negative effect in the school environment, and usually results in poor success, or achievement of such a level of success below the actual level of ability of an individual (2). Fear of the exam is a result of the need to pass the exam. It can occur as early as in primary or secondary school, at others after a failure at the exam or loss of a year on studies.

Academic success for several decades back has been attracting attention of researchers, resulting in a large number of studies examining various factors contributing to the success and failure of students.

Fear of examination or test anxiety is defined as a complex multidimensional concept that includes cognitive, affective, physiological and behavioral responses to situations that require valuation (3). It is considered a special form of general anxiety that occurs during the exam period. Its signs are stress and anxiety or anguish, which is expressed in the course of the examination, with particular perception of helplessness (4). Since students with test-anxiety in test situations demonstrate greater frequency and intensity of emotional reactions, a test situation can be considered a situation-specific anxiety indication (5). Students with high anxiety during exam experience more frequent and more intense emotional reactions related to anxiety and increased activity of the autonomic nervous system. At the same time, there is a division of attention to the demands posed by the task and cognitive activities such as anxiety and self-criticism, which are irrelevant to the task, but lead to reduced attention and indirectly affect achievement.

During the pre-exam anxiety a set of learning difficulties appears: wandering thoughts, difficulty in memorizing, students just „stare” at the book. Learning becomes difficult and inefficient. Time devoted to learning is used irrationally, as well as student's skills. There is imbalance in the work and rest regime, weariness comes quickly while concentration rapidly declines and attention degrades Although a student continues to learn and tries hardly, the results become weaker, inevitably leading to failure (6).

The consequences of poor coping with the pre-exam anxiety may be the inability to pass an exam, reduced success of studies, leaving the faculty, the decline in self-esteem, unused intellectual potential (7). Self-directed attention, according to Clark and Wells model (8) has a key role in maintaining social anxiety. It is defined as an ,awareness of internally created information essential for a person" (9). The content of this awareness may include information about events in the body or awareness of thoughts and emotions including personal beliefs and attitudes. We can say that the focus on oneself is a key factor for test anxiety, too, for assessment of self-efficacy, and an awareness of own automatic thoughts. On the other hand, a small number of students is familiar with the way to deal with pre-exam anxiety (7).

The aim of our study was to investigate the presence of pre-exam anxiety in nursing students and establish the relationship of the pre-exam anxiety and several demographic variables (e.g., gender, age, place of birth, current place of residence, with whom they live, whether they are employed, average family earnings, year of study), objective success (e.g., pass rate at exams, the average score at the end of the year, the possible repeated year of study), and finally subjective perception of academic success (selfsatisfaction as a student as well as the importance of grades obtained at the exam). The sample consisted of students of High Medical College of Professional Studies in Belgrade at the study Department for a professional nurse.

\section{MATERIAL AND METHODS}

The study was conducted in High Medical College of Professional Studies in Belgrade, during the June exam period in the school year 2014/15. The study included 209 students distributed by years of study, chosen randomly. Of the total number of respondents, the sample consisted of $49.3 \%(n=103)$ of the second year students, and $50.7 \%$ $(n=106)$ of the third year students. The average age of respondents was 24.11 years $(\mathrm{SD}=6.26)$. Among the respondents there were 9.1\% $(n=19)$ male students and $90.9 \%$ $(\mathrm{n}=190)$ female students which is common sex distribution in this kind of a study program. Of the total number surveyed, the $4.3 \%(n=9)$ has repeated a year of study. Participants in the research voluntarily and anonymously completed questionnaires right before the test or oral exam lasting 15-20 minutes. All students answered in the same way to the same questions. Though respondents were voluntary, and their participation was anonymous, they were also assured that their responses were confidential. Finally, objective success was evaluated through exam results, grade point average and year of study repeated.

\section{Instruments}

Pre-examination anxiety among students was examined using a questionnaire The Test Anxiety Inventory TAI (the questionnaire was used in order to examine the pre-examination anxiety)(10) and it is most often used in surveys on student population. The questionnaire comprises of 20 questions. Respondents answer questions on a four-point Likert scale: 1 , never; 2 , sometimes; 3 , often; 4 , always. The minimum score of the questionnaire is 20 and the maximum 80. TAI questionnaire includes subscale scores: overall test anxiety (TAI-T) based on all 20 items, test of anxiety-worry (TAI-W) and the test of emotionality - (TAI-E). Each subscale consists of 8 questions. The other four issues are correlated with the remaining sixteen ones. Questions in the subscale "Worry" refer to the cognitive aspects of test anxiety, that is the experience of anxi- 
ety when thinking about the examination outcome in the sense of failure, bad grade and the like. Questions in the subscale "Emotions" refer to the emotional and physiological aspects of anxiety (such as tachycardia, muscle tension, panic) occurring before, during and after the test/exam. Questions in our questionnaires used in this study are very reliable - Cronbach alpha coefficient was 0.94 for the entire questionnaire, and there were no significant changes in any of the individual values of the subscales.

The instrument was applied collectively, during the examination period. First they got the instructions, then filled out indicated questionnaires, and after completion of the test the aim of the study was explained to them.

\section{Statistical data processing}

With respect to descriptive and analytical statistical methods were used to analyse the data. The results were shown by arithmetic mean, standard deviation and relative frequencies. For determining the significance of differences, Student's t-tests and ANOVA tests were performed. Statistical processing of demographic data (as categorical variables) was performed using a chi-square test. The statistical significance here was determined at the $\mathrm{p}<0.05$ level.

\section{RESULTS}

The mean value of the pre-exam anxiety in students of High the Medical College of Professional Studies in Belgrade, measured with the TAI questionnaire was 46.46 $(S D=12.62)$. The mean value of the subscales were, for Emotions $=19.72(\mathrm{SD}=5.73)$ and Worry $=16.99(\mathrm{SD}=5.03)$. The results are shown in Table 1 .

The results obtained from the TAI questionnaire analysis indicate that there are symptoms of the pre-exam anxiety in relation to sex. Students showed statistically highly significant differences in all scores, and it is due to the fact that the observed scores average values are always higher in female students in relation to men, either by comparing the obtained values of the total questionnaire score $\mathrm{t}=-3,007 ; \mathrm{p}<0.05$ or by comparing the observed Emotionality subscales $(\mathrm{t}=-2.983 ; \mathrm{p}<0.05)$ and Worry $(\mathrm{t}=-2.464 ; \mathrm{p}<0.05)$. The results are shown in Table 2 .

Using a t-test to compare questionnaire scores, we showed that pre-exam anxiety symptoms were significantly more pronounced among second-year students than among third-year students for each of the se subscales. This was true in relation to questionnaire total scores $(\mathrm{t}=$ 2.72; $\mathrm{p}<0.01)$ and in relation to the Emotionality subscale $(\mathrm{t}=4.15 ; \mathrm{p}<0.01)$ and the Worry subscale $(\mathrm{t}=3.82 ; \mathrm{p}<0.01)$. When comparing the scores of second- and thirdyear students' scores, statistically significant differences between them were observed with respect to the questionnaire's score overall (mean $=49.73, \mathrm{SD}=11.49 ; \mathrm{p}<0.01)$ the Worry subscale (mean $=17.94, \mathrm{SD}=4.64 ; \mathrm{p}<0.01$ ) and the Emotionality subscale (mean=21.33; $\mathrm{SD}=5.35 ; \mathrm{p}<0.01$ ) among the secondand third-year students. The results are shown in Table 3.
Table 1. Pre-examination anxiety measured by the TAI questionnaire

\begin{tabular}{lcc}
\hline Subscale & Mean & SD \\
\hline TAI-T/ Total score & 46.46 & 12.62 \\
TAI-W / Worry & 16.99 & 5.03 \\
TAI-E / Emotionality & 19.72 & 5.73 \\
\hline
\end{tabular}

Table 2. Pre-examination anxiety obtained by comparing students by sex

\begin{tabular}{lcccc}
\hline Subscale & Gender & Mean & SD & P \\
\hline \multirow{2}{*}{ TAI-T/ Total score } & Male & 38.32 & 11.21 & \multirow{2}{*}{.003} \\
& Female & 47.28 & 12.49 & \\
\multirow{2}{*}{ TAI-W / Worry } & Male & 14.32 & 4.45 & \multirow{2}{*}{015} \\
\multirow{2}{*}{ TAI-E / Emotionality } & Female & 17.26 & 5.02 & \\
& Male & 16.05 & 4.68 & \multirow{2}{*}{.003} \\
\hline
\end{tabular}

Using t-tests, we found that there were no statistically significant differences in exam anxiety intensity with respect to students' place of birth. Among average values for each of the three scores we see that the averages for all scores were higher for students born in Belgrade than for those born in the interior of Serbia; however, therese were not statistically significant differences, whether at the level of the entire questionnaire $(t=1.901 ; \mathrm{p}>0.05)$, nor for the Emotionality $(\mathrm{t}=1.561 ; \mathrm{p}<0.05)$ and Worry subscales $(\mathrm{t}$ $=1.800 ; \mathrm{p}>0.05)$. The results are shown in Table 4 .

A comparison of score averages and their relation to students' current residence showed that average values for students who lived in suburbs were always higher; students who lived in the countryside were always the lowest; while, while students living in the city had scores in the middle across all of the subscales.

The results of the ANOVA test using Tukey comparisons indicate that statistically significant differences were not determined when comparing the results from the entire questionnaire $(\mathrm{F}=.131 ; \mathrm{p}>0.05)$, or from the Emotionality subscales $\mathrm{y}(\mathrm{F}=.037 ; \mathrm{p}>0.05)$ or the Worry subscales

Tablea3. The intensity of the pre-exam anxiety in relation to the year of study

\begin{tabular}{lccrc}
\hline \multicolumn{1}{c}{ Subscale } & $\begin{array}{c}\text { Year of } \\
\text { study }\end{array}$ & Mean & SD & P \\
\hline \multirow{2}{*}{ TAI-T/ Total score } & II & 49.74 & 11.49 & .000 \\
& III & 43.25 & 12.90 & \\
TAI-W / Worry & II & 17.94 & 4.63 & .007 \\
& III & 16.07 & 5.26 & \\
TAI-E / Emotionality & II & 21.34 & 5.36 & .000 \\
& III & 18.16 & 5.68 & \\
\hline
\end{tabular}

Table 4. Average values for the scores in relation to the student's place of birth

\begin{tabular}{lcccc}
\hline Subscale & $\begin{array}{c}\text { place of } \\
\text { birth }\end{array}$ & Mean & SD & P \\
\hline \multirow{2}{*}{ TAI-T/ Total score } & Belgrade & 49.12 & 12.52 & .05 \\
& Inland & 45.43 & 12.56 & \\
TAI-W / Worry & Belgrade & 18.00 & 4.95 & .07 \\
& Inland & 16.62 & 5.03 & \\
TAI-E / Emotionality & Belgrade & 20.71 & 5.73 & \multirow{2}{*}{.12} \\
& Inland & 19.34 & 5.71 & \\
\hline
\end{tabular}




\begin{tabular}{|c|c|c|c|c|}
\hline Subscale & $\begin{array}{c}\text { Residential } \\
\text { status }\end{array}$ & Mean & SD & $\mathbf{P}$ \\
\hline \multirow[t]{3}{*}{ TAI-W / Worry } & city & 16.91 & 5.10 & \multirow{3}{*}{.759} \\
\hline & suburb & 17.56 & 4.85 & \\
\hline & village & 16.62 & 4.94 & \\
\hline \multirow[t]{3}{*}{ TAI-E / Emotionality } & city & 19.69 & 5.72 & \multirow{3}{*}{.964} \\
\hline & suburb & 19.97 & 5.90 & \\
\hline & village & 19.62 & 5.97 & \\
\hline \multirow[t]{3}{*}{ TAI-T / Total score } & city & 46.28 & 12.64 & \multirow{3}{*}{.877} \\
\hline & suburb & 47.47 & 12.84 & \\
\hline & village & 46.06 & 12.77 & \\
\hline
\end{tabular}

$(\mathrm{F}=.276 ; \mathrm{p}>0.05)$. Students with the most prominent symptoms of pre-exam anxiety lived in suburbs, while those with the least lived in the countryside. This is true even though the score averages were about the same for all three types of settlements where the students lived. The results are shown in Table 5.

A comparison of score averages and their relation to students' current residence showed that average values for students who lived in suburbs were always higher; students who lived in the countryside were always the lowest; while students living in the city had scores in the middle across all of the subscales.

The results of the ANOVA test using Tukey comparisons indicate that no statistically significant differences existed in results for the entire survey $(F=.947 ; \mathrm{p}>0.05)$ or for those associated with the Emotionality $(\mathrm{F}=1.089 ; \mathrm{p}<0.05)$ and Worry subscales $(\mathrm{F}=1.037$; $\mathrm{p}<0.05)$. Students with the most prominent pre-exam anxiety symptoms lived with a boyfriend/girlfriend, and those with the least anxiety with a roommate in a rented apartment. The results are shown in Figure 1.

\begin{tabular}{lcccc}
\multicolumn{5}{l}{ Table 6. Average values for the scores with respect to employment } \\
\hline Subscale & $\begin{array}{c}\text { Are you } \\
\text { employed }\end{array}$ & Mean & SD & P \\
\hline \multirow{2}{*}{ TAI-T/ Total score } & Yes & 46.04 & 12.26 & .728 \\
& No & 46.68 & 12.85 & \\
TAI-W / Worry & Yes & 16.75 & 4.93 & .610 \\
& No & 17.12 & 5.10 & \\
TAI-E / Emotionality & Yes & 19.50 & 5.58 & .679 \\
& No & 19.85 & 5.83 & \\
\hline
\end{tabular}

A comparison of averages for the three observed scores in relation to students' employment status (i.e., whether employed or not) showed no statistically significant differences in any questionnaire scores, that is average values were not significantly different with respect to candidate's employment status (i.e., whether he/she was employed or not).

Comparing the scores from the TAI questionnaire with the help of t-tests, we see no significant differences in the intensity of the pre-exam anxiety between students who were employed and those who were not. However, students who were not employed showed pronounced symptoms of anxiety compared to those who worked, yet statistically significant differences were not found when comparing responses drawn from the entire questionnaire $(t=-0.348, p>0.05)$, nor when comparing scores on either the Emotionality $(\mathrm{t}=-0.414, \mathrm{p}>0.05)$ or Worry subscales $(\mathrm{t}$ $=-0.510, \mathrm{p}>0.05)$. The results are shown in Table 6 .

Next, a comparison of the three observed averages with respect to whether a candidate usually passed their exams the first time they are administered showed a statistically highly significant relationship with academic achievement. This relationship is a consequence of the fact that all observed mean scores were always higher among students who tended to fail the same exam and whose who tended to pass their exams the first time they take it.

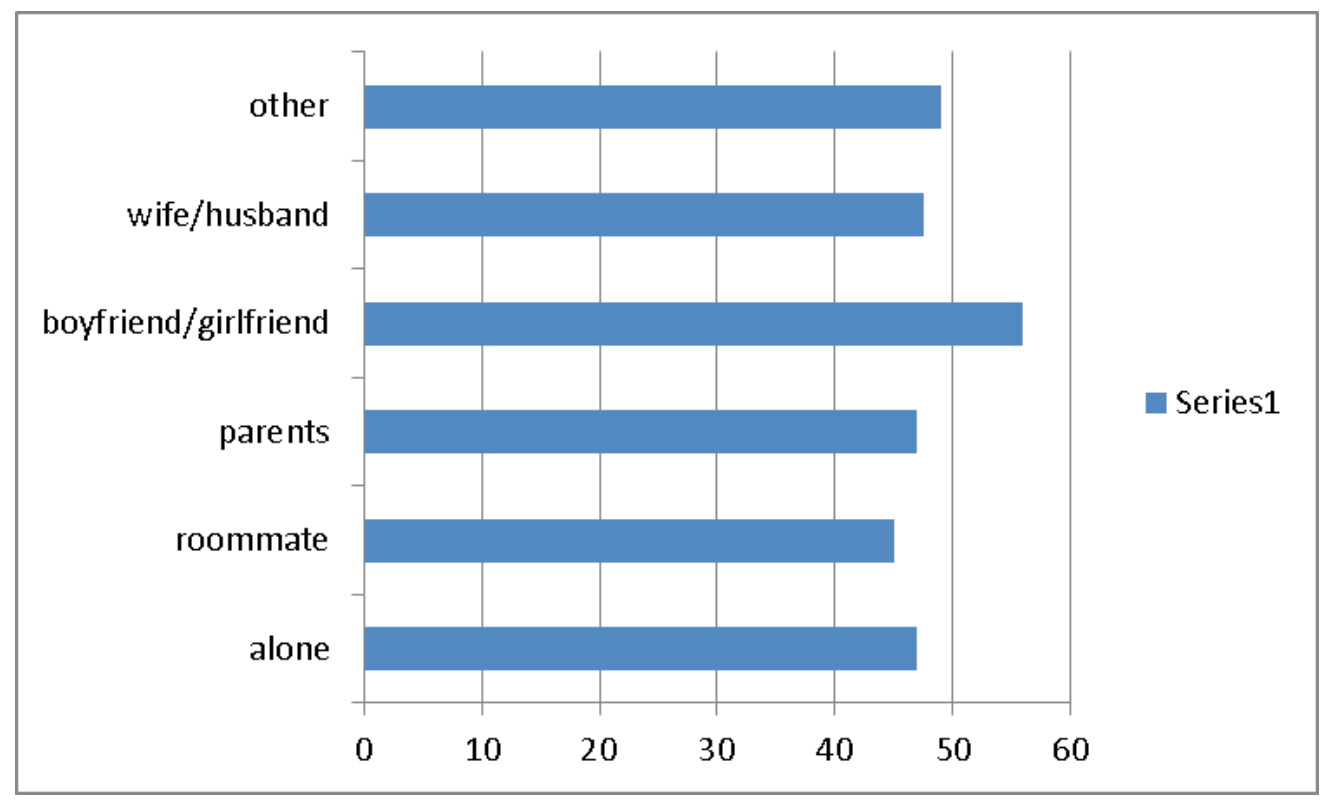

Figure 1. The values for the scores in relation to with whom the student is currently living 
Table 7. Average values of the scores compared to the pass rate at exams

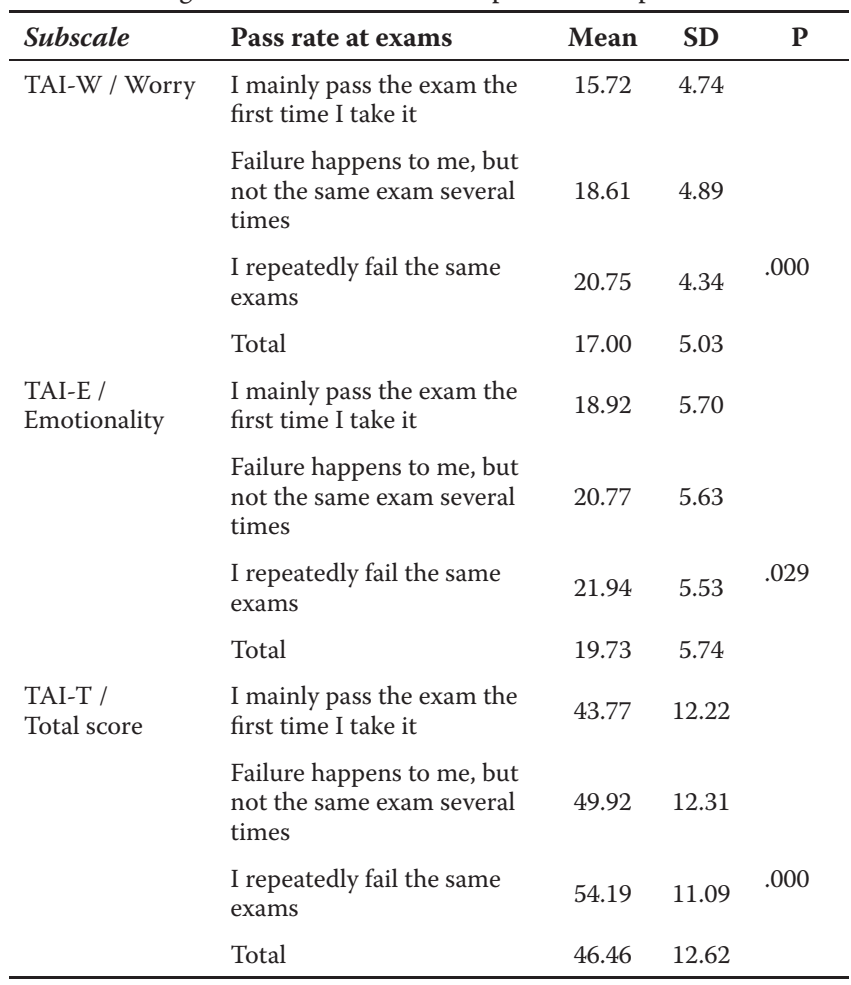

Table 8. The intensity of the pre-exam anxiety in relation to the repeated year of study

\begin{tabular}{lcccc}
\hline Subscale & $\begin{array}{c}\text { Have you ever } \\
\text { repeated a year } \\
\text { of study }\end{array}$ & Mean & SD & P \\
\hline \multirow{2}{*}{ TAI-T/ Total score } & Yes & 49.78 & 12.78 & .422 \\
TAI-W / Worry & No & 46.31 & 12.63 & \\
& Yes & 19.33 & 5.39 & .155 \\
TAI-E / Emotionality & No & 16.89 & 5.00 & \\
\hline
\end{tabular}

Using the t-test to compare TAI questionnaire parameters of students who had andwith students who had not, repeated a year of study, showed no significantly different intensity of pre-exam anxiety. Students who had repeated years showed pronounced symptoms of anxiety compared to those who studied regularly, but a statistically significant difference was not observed when comparing their results on the entire questionnaire $(t=0.805 ; \mathrm{p}>0.05)$, or on their scores from the Emotionality $(\mathrm{t}=0.027$; $\mathrm{p}>0.05)$ or Worry subscales $(\mathrm{t}=$ 1.429; $\mathrm{p}>0.05)$. The results are shown in Table 8.

Subjective perception was measured through the selfsatisfaction of oneself as a student and the importance of the obtained evaluation.

Comparing averages for the three aspects in relation to how much the candidate is pleased with him/herself as a student confirmed the existence of statistically significant differences in the total scores and in the worry scores, while emotionality scores did not show statistical significance.

The results of ANOVA test with Tukey comparison indicate statistically significant differences when comparing the obtained results of the entire survey $(\mathrm{F}=2.750$; $\mathrm{p}$ $<0.05)$ as well as at the Worry subscale $(\mathrm{F}=4.180$; $\mathrm{p}<0.05)$. A statistically significant difference was not found only on the Emotions subscale ( $F=1.849 ; \mathrm{p}>0.05)$. Students with the most prominent symptoms of pre-exam anxiety are also the least satisfied with themselves as students. The

results are shown in Table 9.

Table 9. Pre-examination anxiety was measured through the self-satisfaction as a student

\begin{tabular}{|c|c|c|c|c|c|}
\hline Subscale & Pass rate at exams & Mean & SD & $\mathbf{F}$ & $\mathbf{P}$ \\
\hline \multirow[t]{5}{*}{ TAI-W / Worry } & Satisfied, I learn the best I can & 15.83 & 5.10 & & \\
\hline & Partially satisfied, I could study better & 17.31 & 4.76 & & \\
\hline & Dissatisfied, but I do not have the will to do better than this & 19.40 & 5.76 & 4.18 & .007 \\
\hline & Dissatisfied, I try much, but to no success & 29.00 & . & & \\
\hline & Total & 17.00 & 5.03 & & \\
\hline \multirow[t]{5}{*}{ TAI-E / Emotionality } & Satisfied, I learn the best I can & 19.12 & 6.05 & & \\
\hline & Partially satisfied, I could study better & 19.93 & 5.48 & & \\
\hline & Dissatisfied, but I do not have the will to do better than this & 19.80 & 6.25 & 1.85 & .139 \\
\hline & Dissatisfied, I try much, but to no success & 32.00 & . & & \\
\hline & Total & 19.73 & 5.74 & & \\
\hline \multirow[t]{5}{*}{ TAI-T / Total score } & Satisfied, I learn the best I can & 44.35 & 13.12 & & \\
\hline & Partially satisfied, I could study better & 47.11 & 12.08 & & \\
\hline & Dissatisfied, but I do not have the will to do better than this & 48.90 & 13.16 & 2.75 & .044 \\
\hline & Dissatisfied, I try much, but to no success & 76.00 & . & & \\
\hline & Total & 46.46 & 12.62 & & \\
\hline
\end{tabular}




\section{DISCUSSION}

The High Medical School of Professional Studies in Belgrade is the only school in Serbia with several decades of tradition where, in addition to nurses, eight other professions are educated. This school is one of the most prestigious institutions of higher education, as evidenced not only by the school's admission selectivity but also by the high percentage of graduates employed. The challenges of modern medical education, along with the plans and programmes of the medical school itself, entail numerous obligations and demanding examinations that affect students' mental and emotional status. Intensive multi-year education and the high standards of medical sciences in general suggest that medical sciences students are of a type, one with a high degree of pre-exam anxiety (10).

As a result, there is a need for the continual evaluation of pre-exam anxiety and its effects on the student population. There are numerous global studies on the subject of pre-exam anxiety in nursing students, and most of them confirm the existence of this phenomenon, only to greater or lesser degrees $(11,12)$. However, these studies used different research methodologies, which complicates the comparison of the results of different studies.

With the objective of determining the presence of the pre-exam anxiety, our analysis of the TAI questionnaire results showed that nursing students were statistically significant for pre-exam anxiety across all subscales. Preexam anxiety symptoms related to the sex of the candidates showed highly significant statistical differences in all scores because the observed average scores were always higher in female students relative to men. This was true when comparing questionnaire's total score or when comparing the observed Emotions and Worry subscales. The mean values obtained by the TAI questionnaire for male and female students and for the Emotionality and Worry subscales appeared similar to student population normative data obtained by the questionnaire's author (13).

The results of pre-exam anxiety showed that female students felt greater discomfort and worried more than male ones. They also confessed to having poorer concentration on tests, were and were more likely than men to suggest that thoughts about the exam itself could paralyze them. Female students were also likely to claim that they had more prominent physical symptoms prior to examinations (i.e., rapid heartbeat, stomach discomfort, sweating and flushing). Similar results were obtained from other

studies using the same methodology. Reteguiz found that female medical students had statistically significant higher scores on the TAI questionnaire and on both subscales (14). Some authors explain this difference as reflecting the fact that females have a greater willingness to admit their anxiety than males (15). However, it is possible that women students have higher levels of anxiety than their male counterparts.
In our research, pre-exam anxiety symptoms are significantly more pronounced across all subscales for secondyear students compared to third-year students.

Students with the most prominent pre-exam anxiety symptoms live in suburbs, while those with the least prominent ones live in the countryside. However, the average scores across all three development types are about the same. Based on these results, we can conclude that respondents' place of residence has no particular impact on pre-exam anxiety. Nevertheless, the actual student experiences suggest that those who study outside of their place of residence are under greater pressures in light of the higher total living costs during their studies.

Students with the most prominent symptoms of preexam anxiety lived in partnerships with a boyfriend/girlfriend, while those living with a roommate in a rented apartment had the least anxiety.

This result can be interpreted only partially because there are no data on whether those living with roommates also study with them. We can only assume that these roommates are also students, that they are learning together and sharing their experiences and that they have similar ways of studying, ultimately "reducing" pre-exam anxiety. It would be extremely important to include this parameter in a future studies.

Comparing TAI questionnaire parameters using a ttest showed that employed students had no significant differences pre-exam anxiety intensity than unemployed students. Unemployed students showed pronounced symptoms of anxiety compared to those who worked, and a statistically significant difference was determined based on results from the entire questionnaire. We can assume that employed students are more burdened by everyday business and professional activities, yet they are also more experienced with techniques related to overcoming anxiety, and thus show reduced levels of pre-exam anxiety.

Regarding student performance on examinations, results indicate highly significant statistical differences when comparing the results from the entire survey and when comparing scores from the Emotionality and Worry subscales.

Students with the most prominent pre-exam anxiety symptoms happened to repeatedly fail the same exam, while students the lowest anxiety levels were those who had passed the exams the first time taking them.

This result is expected. Given the high levels of anxiety associated with the exam experience, the more frequent and more intense emotional reactions related to anxiety and the increased activity of the autonomic nervous system, it is not surprising that students are being trippedup during specific exam activities. As mentioned above, Spielberger and Vagg stipulated that multiple concerns and thoughts directed at oneself can emerge simultaneously, and though irrelevant to the task, they can influence the operation of one's attention and performance on exams, indirectly affecting achievement (5). The link between anxiety and test performance was also recognized in Def- 
fenbacher's research, distinguishing the different connections between the components of care and academic success, in both high school pupils and students (16).

On the other hand, there was no statistically significant difference in intensity of pre-exam anxiety symptoms between students who had repeated a year of study and those who entered it for the first time. Students with the most prominent pre-exam anxiety symptoms were those least satisfied with themselves as students. This is a consequence of the fact that observed mean scores were always higher in students who claimed to be neither happy with themselves, nor with the academic success they had achieved. Indeed, scores were always lowest among students who claimed to be happy with themselves and who had done their best. This finding is also not surprising. According to several authors, the consequences of overcoming pre-exam anxiety poorly may be an inability to study, reduced academic performance, reduced self-esteem and unused intellectual potential (7). Our results are consistent with these earlier findings.

\section{CONCLUSION}

The high level of pre-exam anxiety among medical students stems from several years of intensive training in the medical sciences. More than in other fields, these students deal with quick and intensive changes daily and with the constant introduction of new and higher standards. Our motive to analyze is pre-exam anxiety among the High Medical School students was rooted in our awareness of the high degree of pre-exam anxiety in nursing students around the world. Previous researches results, regardless of methodologies used, confirm our own findings: there is a high degree of pre-exam anxiety in nursing students.

The higher level of pre-exam anxiety described in our study was evident in the female students. They

stated (more frequently than their male counterparts) that they had low concentration for the exams and that the very thought of the exam could paralyze them. Additionally, female students had more pronounced physical symptoms prior to an examination with respect to a more rapid heartbeat, stomach discomfort, sweating and flushing. Our research has also shown that a students' place of residence has no particular impact on pre-exam anxiety; however, actual student experiences suggest that students who study outside of their place of residence are under greater pressures as their total living costs during their studies is correspondingly higher.

A very interesting and important finding in this research was that students with the most prominent symptoms of pre-exam anxiety tend to live with a boyfriend/ girlfriend, while those with the least anxiety tended to live with a roommate in a rented apartment. We could only partially interpret this finding asbecause we had no data on whether those living with a roommate were also studying with them. We can only assume that roommates are also learning together, sharing experiences and studying in similar ways, ultimately reducing any pre-exam anxiety. It would be extremely important to include this parameter in subsequent research.

In addition, unemployed students have demonstrated more pronounced anxiety symptoms compared to the employed ones. However, a statistically significant difference was not found when the results from the entire questionnaire were compared. Employed students are probably more burdened by everyday business and professional activities, yet also more experienced in techniques for overcoming anxiety and hence have reduced levels preexam anxiety.

Students at the High Medical College of Professional Studies in Belgrade examined here had very little theoretical knowledge of methods and techniques for overcoming pre-exam anxiety. This work's contribution lies in its focus on the "initial state", identifying the high degree of pre-exam anxiety in nursing students and its proposal for the improvement of this aspect of their education. Their education should entail the expansion individual competences, a capacity to accept responsibility for their own lives, and for enriching the repertoire of adaptive and developmentally useful responses to serious and stressful situations.

\section{REFERENCES}

1. Latas M., Lečić Toševski D. Anxiety disorders. In: Jašović Gašić M, Lečić Toševski D. (2007). A textbook for psychiatry for medical students. Belgrade: Medical faculty. 156-169.

2. Birenbaum, M., Nasser, F. (1994). On the relationship between test anxiety and test performance. Measurement and Evaluation in Counseling and Development, 21, 293-302.

3. Hong, E., Karstensson, L. (2002). Antecedents of state test anxiety. Contemporary Educational Psychology. 27. 348-367.

4. Dykeman, B.F. (1994). The effects of motivational orientation, self-efficacy and feedback condition on test anxiety. Journal of instructional Psychology. 21. 114-120.

5. Spielberger, C.D. , Vagg, P.R. (1995). Text anxiety: transactional process model. U C.D. Spielberg i P.R. Vagg (Ur.), Test anxiety: theory, assessment and treatment (3-15). Washington: Taylor \& Francis.

6. Erić, Lj. (1977) Fear of exam: his nature and healing. Medical book. Belgrade. 55.

7. Neuderth S., Jabs B., Schimdtke A. (2009). Strategies for reducing test anxiety and optimizing exam preparation in German university students: a prevention-oriented pilot project of the University of Würzburg. J Neural Transm. 116(6). 785-790.

8. R.G. Heimberg, M.R. Liebowitz, D.A. Hope, F.R. Schneier (1995). Social Phobia: Diagnosis, Assessment, and Tretment. (p.p. 69-93). New York: The Guilford Press. 
9. Ingram, R.E. (1990). Self-focused attention in clinical disorders: Review and conceptual model. Psychological Bulletin. 107. 156-176.

10. Rosario P., Nunez JC, Salgado A., Gonzalez-Pienda JA, Valle A., Joly C. (2008). Test anxiety: associations with personal and family variables. Psicothema. 20/4. 563-570.

11. Nitasha Sharma, Amandeep Kaur. (2011) Factors associated with stress among nursing students. Nursing and Midwifery Research Journal. 7/1.

12. April L. Shapiro. (2014). Test anxiety among nursing students: A systematic review. Teaching and Learning in Nursing. 9/4. 193-202.

13. Spielberger, C.D. Gonzales, H.P. Taylor, C.J. Anton, E.D. Algaze, B. Ross,G.R. et al. (1980) Manual for the test
Anxiety Inventory “Test Attitude Inventory”. Redwood City, CA: Consulting Psychologists Press.

14. Chapell MS, Blanding B, Silverstein ME, et al. (2005). Test anxiety and academic performance in undergraduate and graduate students. Journal of Educational Psychology. 97/2. 268-274.

15. Rohe DE, Barrier PA, Clark MM, Cook DA, Vickers KS, Decker PA. (2006). the benefits of pass-fail grading on stress, mood, and group cohesion in medical students. Mayo Clin. 81/11. 1443-1448.

16. Deffenbacher, J.L. (1980). Worry and emotionality in test anxiety. U I.G. Sarason (Ur.), Test anxiety: theory, research and applications. (p.p.111-128). New Jersey: Lawrence Earlbaum Associates, Inc. 